\title{
Web Sitesi Hizmet Kalitesinin Müşteri Memnuniyetine Etkisi
}

The Effect of Website Service Quality on Customer Satisfaction

\author{
Özge KOCABULUT*, Tahir ALBAYRAK** \\ *Arş. Gör., Akdeniz Üniversitesi, Turizm Fakültesi, Turizm İşletmeciliği, 07058 Kampus, Antalya. \\ E-posta: ozgekocabulut@akdeniz.edu.tr \\ ORCID: 0000-0002-9774-6911 \\ **Doç. Dr., Akdeniz Üniversitesi, Turizm Fakültesi, Turizm İşletmeciliği, 07058 Kampus, Antalya. \\ E-posta: tahiralbayrak@akdeniz.edu.tr \\ ORCID: 0000-0001-6961-0550
}

MAKALE BILGILERI

Makale işlem bilgileri:

Gönderilme tarihi: 14 Mart 2017

Düzeltme: 10 Mayıs 2017

Kabul: 26 Mayıs 2017

Anahtar sözcükler: Müşteri memnu niyeti, Doğrusal olmayan ilişki, Web sitesi hizmet kalitesi, Ceza-ödül karşıtlığı analizi.

\section{ARTICLE INFO}

Article history:

Submitted: 14 March 2017

Resubmitted: 10 May 2017

Accepted: 26 May 2017

Key words: Customer satisfaction, Nonlinear relationship, Website service quality, Penalty-reward contrast analysis.

\begin{abstract}
ÖZ
Araștırmacılar genellikle ürün özelliklerinin performansı ile müșteri memnuniyeti arasında doğrusal bir ilișki bulunduğu varsayımını benimsemektedir. Ancak son yıllarda gerçekleștirilen birçok araștırma, bu ilișkinin doğrusal yönlü olmayabileceğini göstermiştir. Bu çalışmada, ulusal bir havayolu işletmesine ait web sitesinin hizmet kalitesi ile müşteri memnuniyeti arasındaki ilişki, doğrusal ve doğrusal olmayan yaklaşımların karşılaştırılması yoluyla incelenmiștir. Açıklayıcı faktör analizi sonucu "kolaylık ve cevaplandırma süresi", "eğlence", "güven" ve "özel iletişim" özellikleri web sitesi hizmet kalitesinin başlıca boyutları olarak tespit edilmiştir. Doğrusal ilişkiyi test eden regresyon analizi sonuçlarına göre "kolaylık ve cevaplandırma süresi" boyutu müşteri memnuniyetinin en önemli belirleyicisi olarak tespit edilmiștir. Ancak doğrusal olmayan ilișkiyi test eden ceza-ödül karşıtı̆̆ı analizi sonuçları, dört hizmet kalitesi boyutunun da müşteriler açısından temel faktörler olduğunu göstermiştir. Buna göre, adı geçen özelliklerin performansını arttırmak sadece müşteri memnuniyetsizliğini engellemeye katkı sağlayacak, ancak müşteri memnuniyeti yaratmayacaktır.
\end{abstract}

\begin{abstract}
Researchers assume that there is a linear relationship between product attributes' performance and customer satisfaction. However, recent studies indicated that this relationship could not be linear. In this study, the relationship between website service quality belong to a national airline company and customer satisfaction was investigated by using these two approaches. Based on the exploratory factor analysis, "convenience and response time", "entertainment", "trust", and "special communication" were identified as the dimensions of website service quality. The results of regression analysis revealed that "convenience and response time" was the most important determinant of customer satisfaction. However, four service quality dimensions were identified as the basic factor by penalty-reward contrast analysis. In other words, results revealed that increasing the performance of these attributes only prevent from customer dissatisfaction.
\end{abstract}

\section{GiRiş}

Dünya çapında internet kullanımı giderek yaygınlaşmakta ve kullanıcı sayısında hızlı bir artış yaşanmaktadır. Dijital pazarlama ajansı We are Social'ın raporuna (2016) göre hem dünyada hem Türkiye'de internet kullanıcılarının oranı 2016 yılında bir önceki yıla göre \%10'luk bir artış göstermiştir. Buna göre 7,395 milyarlık dünya nüfusunun \%46'sı (3,419 milyar kişi), 79,14 milyonluk Türkiye nüfusunun ise $\% 58$ 'i (46,3 milyon kişi) internet kullanmaktadır. Aynı rapora göre, internet kullanıcılarının, $\% 54$ 'ü ayda en az bir kere ürün satın almak için web sitelerini ziyaret etmekteyken $\% 45$ 'i web sitelerinden ürün veya hizmet satın almaktadır. Bu durum çevrimiçi işletmeler açısından rekabet avantajı ve yeni iş imkânları sunmaktadır. Bunun yanı sıra bir çok geleneksel işletmenin de çevrimiçi pazara dahil olmasını teşvik etmekte ve küresel rekabetin artmasına yol açmaktadır.

Çevrimiçi işletmelerin rekabet üstünlüğü elde etmesinin yollarından biri rakiplere göre yüksek müşteri memnuniyeti sağlamaktır. Bu maksatla, işletme web sitesi aracılığı ile sunulan hizmetle- 
re yönelik müşteri beklentilerini anlamak ve onların bakış açısı ile web sitesini değerlendirmek son derece önemlidir. Dolayısıyla web sitesi hizmet kalitesinin müşteri memnuniyetine etkisini ve web sitesine ait hangi özelliklerin memnuniyeti daha fazla etkilediğini tespit etmek önem arz etmektedir.

Müşteri memnuniyeti açısından önem arz eden web sitesi özelliklerinin belirlenmesi oldukça karmaşık bir görevdir. Alanyazında genellikle ürün özelliklerinin performansı ile müşteri memnuniyeti arasında doğrusal bir ilişki bulunduğu varsayımı benimsenmiştir. Bu sebeple yapılan çalışmalarda sıklıkla regresyon analizi veya yapısal eşitlik modelleme gibi geleneksel yöntemler kullanılmaktadır. Ancak son yıllarda gerçekleştirilen birçok araştırma, ürün özelliklerinin performansıyla müşteri memnuniyeti arasındaki ilişkinin doğrusal yönlü olmayabileceğini ortaya koymuştur (Johnston 1995; Matzler ve Sauerwein 2002; Matzler vd. 2004; Albayrak ve Caber 2013). Diğer bir ifade ile ürün özelliklerinin müşteri memnuniyeti açısından taşıdığı önem, ilgili özelliğin mevcut performans seviyesine göre değişiklik göstermektedir. Bu nedenle, geleneksel yöntemler kullanıldığında, ürüne ait herhangi bir özelliğin performansını iyileştirmek için yapılan girişimler anlamlı olarak sonuçlanmayabilir. $\mathrm{Bu}$ çalışma, web sitesi hizmet kalitesi özellikleri ile müşteri memnuniyeti arasındaki doğrusal olmayan ilişkiyi bir havayolu rezervasyon kanalını inceleyerek anlamayı amaçlamaktadır. Çalışmanın alt amaçları ise:

(1) Web sitesi hizmet kalitesi boyutlarını belirlemek,

(2) Web sitesi hizmet kalitesi boyutlarının müşteri memnuniyetine doğrusal etkisini incelemek,

(3) Web sitesi hizmet kalitesi boyutlarının müşteri memnuniyetine doğrusal olmayan etkisini ortaya koymaktır.

\section{ALANYAZIN TARAMASI}

\section{Web Sitesi Hizmet Kalitesi}

Web sitesi hizmet kalitesi, bir web sitesinin verimli ve etkili alışverişe, ödemeye ve teslim süre- cine ne ölçüde olanak sağladığı ile açıklanmaktadır (Parasuraman vd. 2005). Bu tanım; web sitesi hizmet kalitesi kavramının, ön ödeme evresinden (kullanım kolaylığı, ürün bilgisi, sipariş bilgisi ve kişisel bilgi güvenliği gibi) satış sonrası evreye (teslimat, müşteri destek, vaatlerin yerine getirilmesi ve iade politikası gibi) kadar olan tüm süreci kapsadığına açılık getirmektedir. Web sitesi hizmet kalitesinin ölçümüne yönelik önceki çalışmaların bir kısmı geleneksel hizmet kalitesi ölçüm modellerini uyarlarken (örneğin Gefen 2002) diğer bir kısmı web sitesi hizmet kalitesine özgü ölçüm modelleri geliştirmiştir (örneğin Yang vd. 2005). Ancak Parasuraman ve Grewal (2000) geleneksel hizmet kalitesi ölçüm modelleri üzerine inşa edilen ölçekleri eleştirerek müşterilerin servis personeliyle kişisel etkileşimi bırakıp teknoloji ile etkileşime geçmeye başladığında, beş hizmet kalitesi boyutunun öneminde ve tanımlamasında değişikliğe ihtiyaç duyulabileceğini belirtmiştir.

Geleneksel hizmet kalitesi ölçüm modellerinin, çevrimiçi hizmet kalitesini değerlendirmek için kapsamlı araçlar olmadığını ileri süren araştırmacılar web sitesi hizmet kalitesini değerlendirmeye yönelik özel ölçüm modelleri önermiştir. Örneğin, Yang vd. (2005) bilgi sunan bir web sitesinde işlem yapan yaklaşık 2000 kullanıcıya yönelik bir araştırma yaparak kullanılabilirlik, içeriğin yararlılığı, bilginin uygunluğu, erişebilirlik ve etkileşim boyutlarından oluşan bir web sitesi hizmet kalitesi ölçeği geliştirmiştir. Yazarların geliştirmiş̧ olduğu bu ölçeğin test edilmesi sonucunda, en başta kullanılabilirlik olmak üzere beş boyutun da kullanıcıların web sitesinin hizmet kalitesini değerlendirmesinde anlamlı bir etkiye sahip olduğu ve web sitesi hizmet kalitesinin kullanıcı memnuniyetini etkilediği tespit edilmiştir. Aladwani ve Palvia (2002) ise tek bir web sitesinde değerlendirme yapmanın doğru sonuçlar vermeyeceğini ileri sürmüş ve birden fazla web sitesinde uygulama yaparak (banka, kitap mağazası, otomobil üreticisi ve elektronik perakendeci) bir ölçek geliştirmiştir. Ölçekte Yang vd.'nin (2005) ulaştı farklı olarak teknik yeterlilik, özel içerik, kaliteli içerik ve web görünümü olmak üzere dört boyut elde edilmiştir. 
Web sitesi hizmet kalitesini değerlendirmek için sıklıkla kullanılan bir başka ölçek de Loiacono vd.'nin (2007) geliştirmiş olduğu 36 ifadeden oluşan WebQual ölçeğidir. Loiacono vd. (2007) alanyazın taraması ve kullanıcılarla yapılan görüşmeler sonucunda 12 temel web sitesi kalitesi boyutuna ulaşmıştır. Yazarlar tarafından geliştirilen bu ölçek daha sonra 800 üniversite öğrencisinin kitap, müzik, havayolu ve otel web sitelerini değerlendirmesi ile test edilmiştir. Ölçeğin geçerlilik ve güvenilirliği yüksek olmasına rağmen, öğrencilerin gerçek anlamda satın almada bulunmamış olması sebebi ile eleştiri almıştır (Xie ve Barnes 2008).

Yakın bir zamanda, Dedeke (2016) tarafından yapılan bir araştırmada, seyahat web sitesi kullanıcılarının (WebQual ölçeği yoluyla) hizmet kalitesi algıları ve satın alma niyetleri arasındaki ilişki incelenmiştir. Araştırma sonucunda web sitesi tasarımının algılanan ürün kalitesini ve çevrimiçi satın alma niyetini etkilediği tespit edilmiştir. Abou-Shouk ve Khalifa (2016) ise Misır'daki seyahat acenteleri ile otellerin web sitelerini karş1laştırdıkları çalışmada web sitesi kalitesinin çevrimiçi satın alma davranışı ve e-sadakat üzerindeki etkisini ele almıştır. Araştırma sonucunda ulaşılan bulgular, WebQual'e ait web sitesi kalite boyutlarının müşterilerin satın alma davranış1nı önemli ölçüde etkilediğini ortaya koymuştur. Ayrıca havayolu sektöründe web sitesi kalitesini değerlendiren Shchiglik ve Barnes (2004), web sitesi kalitesi, bilgi kalitesi, etkileşim kalitesi ve havayolu işletmelerine özgü kalite olmak üzere dört boyuttan oluşan algılanan havayolu web sitesi kalitesi ölçeğini geliştirmiştir. Bu çalışmada, havayolu işletmelerinde yürütülen operasyonlara özgü ifadelerden oluşan "havayolu işletmelerine özgü kalite" boyutunun yer alması önemlidir. Ancak diğer çalışmalardan bu yönü ile farklılık gösterse de alanyazında sıklıkla tercih edilen bir ölçek olarak yerini alamamıştır.

\section{Web Sitesi Hizmet Kalitesi ile Müşteri Memnuniyeti Arasındaki ilişki}

Web sitesi hizmet kalitesi ile diğer değişkenler arasındaki ilişkiyi inceleyen birçok çalışma bulunmaktadır. Bu çalışmalarda, web sitesi hizmet kalitesinin kullanıcıların çevrimiçi güveni (örneğin Wang vd. 2015), web sitesine karşı tutumları (örneğin Hausman ve Siekpe 2009), çevrimiçi ticarete karşı tutumları (örneğin Dedeke 2016), hizmet veya ürün değeri algıları (örneğin Hsu 2008), fazla ödemeye isteklilikleri (örneğin Fassnacht ve Köse 2007), web sitesine bağlllık niyetleri (örneğin Kim ve Niehm 2009), web sitesini tekrar ziyaret etme niyetleri (örneğin Long ve McMellon 2004) gibi birçok değişken üzerinde anlamlı bir etkiye sahip olduğu tespit edilmiştir.

Müşteri memnuniyeti işletme performansının önemli bir belirleyicisi olduğundan, web sitesi hizmet kalitesinin müşteri memnuniyetine olan etkisi birçok çalışmada incelenmiştir (Lee ve Lin 2005; Lin 2007; Fassnacht ve Köse 2007; Ho ve Lee 2007). Örneğin, Jeong vd. (2003) bir konaklama işletmesinin web sitesi kalitesini 1743 müşterinin katılım gösterdiği bir araştırma ile değerlendirmiştir. Çalışma sonucunda memnuniyetin davranışsal niyeti belirleyen önemli bir unsur olduğu ve web sitesi kalitesinin memnuniyetin önemli bir öncüsü olduğu tespit edilmiştir. Ali ve Ali (2016) çevrimiçi seyahat acenteleri veya otel web siteleri aracılığıyla rezervasyon yapan 441 müşteri ile gerçekleştirdiği çalışmalarında, otel web sitesi kalitesi, müşterilerin içsel-psikolojik durumu, müşteri memnuniyeti ve satın alma davranışı arasındaki ilişkiyi incelemiştir. Araştırma bulguları, otel web sitesi kalitesinin, müşterilerin içsel-psikolojik durumu aracılığ 1 ile memnuniyeti etkilediğini ve memnuniyetin de satın alma niyetinin belirleyicisi olduğunu göstermiştir.

İnternetin ve çevrimiçi ticaret uygulamalarının yaygınlaşması, havayolu işletmelerinin de müşteri bakış açısı ile web sitelerini şekillendirmelerini gerekli kılmıştır (Nafchi vd. 2014). Havayolu çevrimiçi rezervasyon kanallarına ait çalışmalar incelendiğinde, web sitesi kalite boyutlarının memnuniyete ve satın alma niyetine olan etkilerini tespit etmeye yönelik araştırmaların büyük çoğunluğu oluşturduğu görülmektedir. Örneğin, Endonezya'daki havayolu şirketlerinin web sitesi kalitelerini değerlendiren Setiandi ve Sardjono (2013) web sitesi hizmet kalitesini oluşturan güven, kullanıcı ara yüzü, bilgi ve etkileşim boyutlarının müşteri memnuniyetini etkilediğini 
tespit etmiştir. Byamba ve Chang (2012), bir havayolu rezervasyon kanalı için etkileşimi, ödeme güvenliğini ve kullanım kolaylığını, çevrimiçi müşteri memnuniyetini etkileyen başlica boyutlar olarak belirlemiştir (Elias vd. 2015). Lee ve Wu'nun (2011) tek bir havayolu işletmesinin web sitesi hizmet kalitesini değerlendirmenin kısıtına dikkat çektiği ve bu doğrultuda Tayvan'daki 30 farklı havayolu işletmesinin web sitesinden uçak bileti satın alma konusunda farklı tecrübelere sahip olan 236 uluslararası yolcu ile gerçekleştirdiği çalışmada, web sitesi hizmet kalitesinin ve algilanan hizmet değerinin memnuniyeti etkilediği belirlenmiştir. Özet olarak, yapılan araştırmalar web sitesinin, işletmeler ile müşteriler arasında önemli bir bağ oluşturduğunu; dolayısıyla web sitesi hizmet kalitesi ile ilgili çalışmaların temelinde yatan arayışın müşteri memnuniyetini etkileyen web sitesi boyutların ortaya koymak olduğunu göstermektedir (Jeon vd. 2003; Kim ve Stoel 2004; Lin 2007; Wang vd. 2015; Dedeke 2016).

\section{Üç Faktör Teorisi}

Kano vd. (1984), Herzberg vd.'nin (1959) iki faktörlü İş Doyumu Teorisi'nden esinlenerek öne sürdükleri teorilerinde, ürün özelliklerinin, müşteri memnuniyetine olan etkileri açısından beş farklı grup altında toplanabileceğini iddia etmiştir. Bu teori, ürün özelliklerini müşteri memnuniyetine doğrusal olmayan etkilerini dikkate alarak, temel, performans, heyecan, ters ve fark yaratmayan faktörler şeklinde beş gruba ayırmaktadır. Kano Modeli olarak bilinen bu teori, araştırmacılara müşteri memnuniyeti için geliştirilmesi gereken birincil ürün özelliklerini tanımlamada yardımcı olan bir yöntemdir. Araştırmacıların genellikle ters ve fark yaratmayan faktörleri dikkate almaması sebebiyle model son zamanlarda Üç Faktör Teorisi olarak ifade edilmeye başlanmıştır. Üç Faktör Teorisi, ürün özelliklerini müşteri memnuniyetine doğrusal olmayan etkilerini göz önüne alarak; temel, performans ve heyecan faktörleri olarak sınıflandırmaktadır (Şekil 1).

Temel Faktörler: Bu faktörler, bir ürünün temel işlevini yerine getirmektedir. Temel Faktörler müşterilere sunulmadığı zaman memnuniyetsizlik yaratan, fakat sunulduğunda memnuniyete

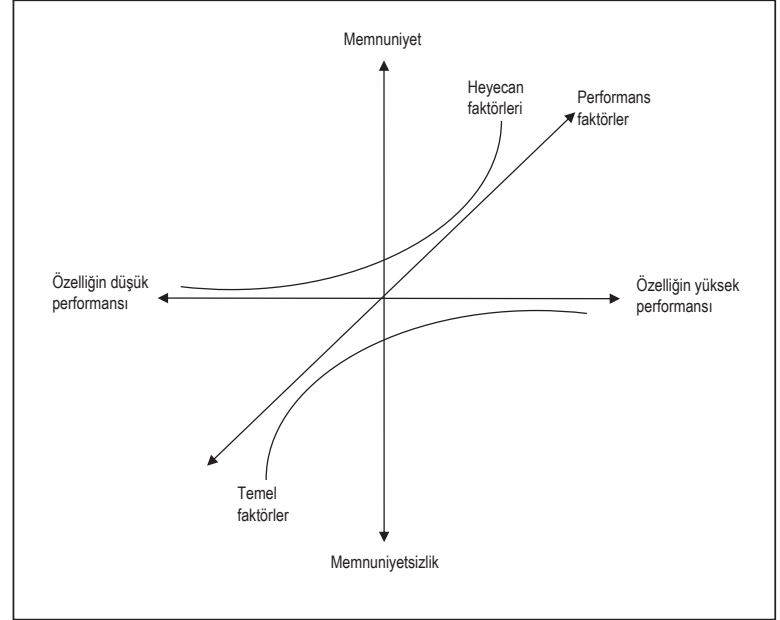

Şekil 1. Üç̧ Faktörün Müşteri Memnuniyetine Etkisi

neden olmayan özelliklerdir (Matzler vd. 2004). Müşteriler bu faktörleri, işletmeler tarafından sağlanması gereken asgari gereklilikler olarak değerlendirmektedir.

Performans Faktörleri: Bu faktörler, müşterilere sunulduklarında memnuniyet, sunulmadıklarında ise memnuniyetsizlik yaratmaktadır. Performans faktörlerine ait algılanan performans ile müşteri memnuniyeti arasında doğrusal bir ilişki vardır. Ürünün bu özelliklerine yönelik performans ne kadar yüksekse müşteri memnuniyeti o kadar yüksek iken performans düşük olduğunda müşteri memnuniyetsizliği o kadar fazla olmaktadir.

Heyecan Faktörleri: Bu faktörler, müşteri memnuniyetinin temel unsurlarıdır. Eğer mevcutlarsa ve performansları yüksekse, yüksek bir memnuniyet düzeyi yaratmaktadırlar. Öte yandan, mevcut değillerse memnuniyetsizlik yaratmamaktadırlar. Heyecan faktörleri müşteri tarafından talep edilmeyen ya da beklenmeyen özelliklerdir. Müşteri için sürpriz niteliği taşıyan bu faktörler, yüksek memnuniyet yaratma potansiyeline sahiplerdir.

Ürün özellikleri ile müşteri memnuniyeti arasındaki doğrusal olmayan ilişkiler, sağlık hizmetleri (örneğin Mittal vd. 1998), bankacılık (Matzler vd. 2004), çevrimiçi alışveriş platformları (örneğin Falk vd. 2010), turizm merkezleri (örneğin Füller ve Matzler 2008) ve web siteleri (örneğin Kim ve Fesenmaier 2008) gibi alanlar- 
da incelenmiştir. Örneğin, web sitesi bilgi kalitesi ile kullanıcı memnuniyeti arasındaki doğrusal olmayan ilişkiyi inceleyen Cheung ve Lee (2009), dört bilgi kalitesi özelliğinden üçünün olumsuz performanslarının müşteri memnuniyetine etkisinin pozitif performanslarına göre daha fazla olduğunu tespit etmiştir. Caber vd. (2013) ise extranet hizmet kalitesine ait boyutları WebQual ölçeği ile tespit ettikten sonra bu özellikleri kullanıcıların (seyahat acentesi satış temsilcisi) memnuniyeti üzerindeki doğrusal olmayan etkileri açısından sınıflandırmıştır. Sonuçlar eğlence boyutunun performans faktörü, yararlılık ve kullanım kolaylığı boyutlarının temel faktör, güven, cevaplandırma süresi ve göreceli fayda boyutlarının ise heyecan faktörü olduğunu göstermiştir. Araştırmacılar üç faktörü tespit etmek için Kano Tekniği, Kritik Olay Tekniği, Önem Matrisi ve Ceza-Ödül Karşıtlığı Analizi gibi yöntemlerden faydalanmaktadır. Ancak Ceza-Ödül Karşıtlığı Analizi müşteri memnuniyeti ölçümünden elde edilen verilerle gerçekleştirilebildiği için diğer yöntemlere kıyasla daha fazla kullanılmaktadır (Albayrak 2015).

\section{ARAŞTIRMANIN YÖNTEMI}

$\mathrm{Bu}$ araştırmanın amaçlarına ulaşmak için, Türkiye'deki Turizm ile İktisadi ve İdari Bilimler Fakültelerinde görev yapmakta olan akademisyenlerin ulusal bir havayolu işletmesinin web sitesine yönelik değerlendirmelerinden faydalanılmıştır. Hedef kitle olarak akademisyenlerin ele alınmasının başlıca sebebi, mesleki nedenlerle sık seyahat etmelerinden ve kolay ulaşılabilir olmalarından kaynaklanmaktadır. Araştırmada kullanılan anket dört bölümden oluşmaktadır. Birinci bölümde, katılımcıların demografik özelliklerini belirlemek amacıyla cinsiyet, yaş, medeni durum ve mesleki unvana yönelik dört soru bulunmaktadır. İkinci bölümde, katılımcıların internet kullanım alışkanlıklarının belirlenmesine yönelik beş soru yer almaktadır (İnternetten günde ortalama kaç saat yararlanıyorsunuz?; İnternet üzerinden bir ay içerisinde ortalama hangi sıklıkta alışveriş yaparsınız? gibi). Üçüncü bölümde, web sitesi hizmet kalitesini değerlendirmek için sıklıkla kullanılan, Loiacono vd.'nin
(2007) geliştirmiş olduğu 36 önermelik WebQual ölçeği yer almaktadır. Dördüncü ve son bölümde ise kullanıcıların genel memnuniyetlerinin ölçümü için Flavián vd.'nin (2006) araştırmasından alınan dört ifade bulunmaktadır. Web sitesi kalitesi ve genel memnuniyet önermeleri 7'li Likert tipi ölçek ile değerlendirilmiştir (1: Kesinlikle katılmıyorum; 7: Kesinlikle katılıyorum). Ankette yer alan ifadeler araştırmacılar tarafından İngilizceden Türkçeye çevrilmiştir. Daha önce aynı ölçekleri kullanan önceki çalışmalarda yer alan Türkçe ifadeler ile araştırmacıların yaptığ 1 tercümeler karşılaştırılarak tutarsızlıklar ortadan kaldırılmıştır. Hazırlanan anket, çevrimiçi anket toplama hizmeti veren bir web sitesine yüklenmiştir. Yükseköğretim Kurumu 2017 verilerine göre Türkiye'de Turizm ile İktisadi ve İdari Bilimler Fakültesi bünyesinde görev yapan toplam 8055 akademisyen bulunmaktadır. Araştırma kapsamındaki fakültelerin web siteleri taranarak, 3327 akademisyene ait elektronik posta adresine ulaşılmıştır. İlgili akademisyenlere elektronik posta gönderilerek çalışmanın amacı açıklanmış ve gönüllü katılımları istenmiştir. 06.12.201606.02.2017 tarihleri arasında üç defa hatırlatma yapılarak katılımcıların anketleri yanıtlaması sağlanmıştır. İki ay sonunda toplam 374 adet kullanılabilir ankete ulaşılmıştır. Buna göre anketin cevaplanma oran $\% 11,24$ olup, bu oran genel olarak çevrimiçi veri toplamada ulaşılan geri dönüş oranları ile benzerlik göstermektedir (örneğin Leece vd. 2004).

\section{BULGULAR}

Katılımcıların \%60,2'si erkek, \%71,4'ü evlidir. Ayrıca katılımcıların \%42'si 31-40 yaş arasında ve \%32,4'ü araştırma görevlisidir (Tablo 1).

Katılımcıların genel internet kullanım yaklaşımları ve ele alınan havayolunun web sitesini kullanımlarına yönelik tercihleri Tablo 2'de gösterilmiştir. Katılımcların \%44,7'si günde ortalama 3-5 saat internet kullanmakta ve $\% 34,8^{\prime} i$ aylık ortalama 2-3 kez internetten alışveriş yapmaktadır. Ayrıca katılımcıların \%43,3'ünün ele alınan ulusal havayolu web sitesinden yılda ortalama olarak 2-3 kez uçak bileti satın aldığı tespit edilmiştir. Katılımcıların internet üzerinden en sık 
Web Sitesi Hizmet Kalitesinin Müşteri Memnuniyetine Etkisi

Tablo 1. Katılımcıların Demografik Özellikleri (N=374)

\begin{tabular}{llrr}
\hline Demografik Değişkenler & $f$ & $\%$ \\
\hline \multirow{2}{*}{ Cinsiyet } & Erkek & 225 & 60,2 \\
& Kadın & 149 & 39,8 \\
\hline Medeni Durum & Bekar & 107 & 28,6 \\
& Evli & 267 & 71,4 \\
\hline Yaş & 30 ve daha küçük & 78 & 20,9 \\
& 31-40 yaş arası & 157 & 42,0 \\
& 41-50 yaş arası & 92 & 24,6 \\
& 51-60 yaş arası & 36 & 9,6 \\
& 61 ve daha büyük & 11 & 2,9 \\
\hline Unvan & Araştirma görevlisi & 121 & 32,4 \\
& Öğretim görevlisi & 62 & 16,6 \\
& Yardımcı doçent doktor & 100 & 26,7 \\
& Doçent doktor & 56 & 15,0 \\
& Profesör & 35 & 9,3 \\
\hline
\end{tabular}

f: Frekans

satın aldığı ürünler sırasıyla; uçak bileti (\%76,5), kitap-CD $(\% 60,7)$, konaklama $(\% 41,7)$ ve giyim $(\% 37,4)$ olarak belirlenmiştir.

Web sitesi hizmet kalitesine yönelik boyutları tespit etmek maksadıyla WebQual ölçeğine ait 36 ifade Varimax döndürme yöntemi ile açıklayıcı faktör analizine tabi tutulmuştur. Öncelikle değişkenler arasındaki ilişki Barlett Küresellik Testi, örneklem sayısının yeterliliği KMO (Kaiser-Meyer-Olkin) değeri ile incelenmiştir. Elde edilen değerler, değişkenler arasında ilişkinin varlığını $(14689,783 ; p<0,01)$ ve örneklem say1sının faktör analizi için yeterli olduğunu $(0,95)$ göstermiştir. Faktör analizi sonucunda, iki boyut altında yakın değerlere sahip dört ifade (web sitesini kolay kullanabilir buluyorum; destek sistemdeki sembol, gösterge veya işaretleri anlamak kolaydır; web sitesindeki görüntü ekranları kolaylıkla okunabilmektedir; web sitesinin yüklenmesi uzun zaman almaktadır) ile silindiğinde boyut güvenilirliğinin artmasını sağlayan dört ifade (web sitesi, hızlı bir şekilde yüklenmektedir; daha fazla bilgisayar kullanma tecrübem olsaydı, web sitesini daha kolay kullanabilirdim; web sitesinde gerçekleştirdiğim işlemlerin tamamlandığına güvenirim; web sitesinden belirli ihtiyaçlarıma yönelik bilgileri edinebilmem mümkündür) analizden çıkarılmıştır. Kalan 28 ifade ile analiz tekrar edilmiş ve özdeğeri birin üstünde, toplam varyansın \%72,23'ünü açıklayan dört faktör elde edilmiştir. Faktörler, içerdikleri
Tablo 2. Katılımciların İnternet ve Havayolu Web Sitesini Kullanım Alışkanlıkları (N=374)

\begin{tabular}{|c|c|c|}
\hline \multicolumn{3}{|c|}{ Günde ortalama internet kullanma süresi (saat) } \\
\hline 1 saatten daha az & 5 & 1,3 \\
\hline 1-2 saat & 60 & 16,0 \\
\hline 3-5 saat & 167 & 44,7 \\
\hline 6 saat veya daha fazla & 142 & 38,0 \\
\hline \multicolumn{3}{|c|}{ Aylık ortalama internet üzerinden alışveriş etme sıklı̆ı } \\
\hline $1 \mathrm{kez}$ & 67 & 17,9 \\
\hline 2-3 kez & 130 & 34,8 \\
\hline 4-5 kez & 59 & 15,8 \\
\hline 6 kez veya üzeri & 20 & 5,3 \\
\hline Yılda birkaç kez & 98 & 26,2 \\
\hline \multicolumn{3}{|c|}{ Ulusal Havayolu web sitesini ziyaret etme sıklığı (yıllık) } \\
\hline $1 \mathrm{kez}$ & 40 & 10,7 \\
\hline 2-3 kez & 101 & 27,0 \\
\hline 4-5 kez & 71 & 19,0 \\
\hline 6 kez veya üzeri & 162 & 43,3 \\
\hline \multicolumn{3}{|c|}{ Ulusal Havayolu web sitesinden bilet satin alma sıklığı (yıllık) } \\
\hline $1 \mathrm{kez}$ & 95 & 25,4 \\
\hline $2-3$ kez & 162 & 43,3 \\
\hline 4-5 kez & 57 & 15,3 \\
\hline 6 kez veya üzeri & 60 & 16,0 \\
\hline \multicolumn{3}{|c|}{ Internet üzerinden en sık satn alınan ürünler* } \\
\hline Uçak Bileti & 286 & 76,5 \\
\hline Kitap-CD & 227 & 60,7 \\
\hline Konaklama & 156 & 41,7 \\
\hline Giyim & 140 & 37,4 \\
\hline Bilgisayar Ekipmanı & 66 & 17,6 \\
\hline Kozmetik & 40 & 10,7 \\
\hline
\end{tabular}

ifadeler ve alanyazın göz önüne alınarak isimlendirilmiştir. 12 ifadeden oluşan birinci faktör "eğlence" olarak isimlendirilmiş olup toplam varyansın \%31,12'sini açıklamaktadır. 12 ifadeden oluşan ikinci faktör "kolaylık ve cevaplandırma süresi" olarak isimlendirilmiş olup toplam varyansın \%26,92'sini açıklamaktadır. İki ifadeden oluşan üçüncü faktör "özel iletişim" olarak isimlendirilmiş olup toplam varyansın $\% 7,35$ 'ini ve iki ifadeden oluşan dördüncü faktör "güven" boyutu olarak isimlendirilmiş olup toplam varyansın \%6,83'ünü açıklamaktadır. Tablo 3'te boyutlara ait faktör yükleri, varyans açıklama oranları ve güvenilirlik katsayıları gösterilmiştir.

Web sitesi hizmet kalitesi boyutları arasında en düşük performans algısı 4,85 ortalama ile "eğlence" boyutuna aittir. Katılımciların en olumlu algiya sahip olduğu boyut 5,76 ortalama ile "kolaylık ve cevaplandırma süresi" dir (Tablo 4). 
Tablo 3. Web Sitesi Hizmet Kalitesi Boyutları

\begin{tabular}{|c|c|c|c|c|}
\hline Web sitesi... & Eğlence & $\begin{array}{r}\text { Kolaylık ve } \\
\text { cevaplandırma süresi }\end{array}$ & Özel iletişim & Güven \\
\hline Görsel açıdan hoş bir şekilde dizayn edilmiştir & 0,742 & & & \\
\hline Görsel yönden çekicidir & 0,813 & & & \\
\hline Görsel açıdan hoştur & 0,818 & & & \\
\hline Yenilikçidir & 0,812 & & & \\
\hline Dizaynı yenilikçidir & 0,839 & & & \\
\hline Yaraticıdır & 0,818 & & & \\
\hline Kullandığımda mutlu oluyorum & 0,747 & & & \\
\hline Kullanmaktan keyif duyuyorum & 0,764 & & & \\
\hline Kullandığımda, kendimi sosyal hissediyorum & 0,691 & & & \\
\hline Şirket imajıyla tutarlı bir imaj yansıtmaktadır & 0,745 & & & \\
\hline Benim algıladığım imajla uygunluk göstermektedir & 0,774 & & & \\
\hline Şrket imajına uygundur & 0,774 & & & \\
\hline Bilgiler, işlemlerimi gerçekleştirebilmem için yeterlidir & & 0,738 & & \\
\hline Bilgilendirilme ihtiyaçlarımı yeterince karşılamaktadır & & 0,701 & & \\
\hline Bilgiler günceldir & & 0,733 & & \\
\hline Tüm işlemleri tamamlayabiliyorum & & 0,622 & & \\
\hline İ̧̧lem süreçlerinin büyük bir kısmını tamamlayabiliyorum & & 0,774 & & \\
\hline $\begin{array}{l}\text { Çevrimiçi işlemlere olanak sağlamaktadır } \\
\text { İ̧lemleri gerçekleştirmem, telefon, faks veya bir şirket temsilcisine mail }\end{array}$ & & 0,822 & & \\
\hline göndermemden daha kolaydır & & 0,702 & & \\
\hline Şirketin satş̧ veya müşteri hizmetlerini aramama bir alternatiftir & & 0,618 & & \\
\hline Şirket temsilcisi ile telefon görüşmesi yapmama nazaran daha kolay & & & & \\
\hline bir işlem yapma yoludur & & 0,760 & & \\
\hline Yazılar kolay okunabilmektedir & & 0,688 & & \\
\hline Kullanmayı öğrenmek benim için kolay oldu & & 0,675 & & \\
\hline Kullandığımda, işlem yapmam ve bunların onaylarını almam arasında & & & & \\
\hline geçen süre oldukça kısadır & & 0,614 & & \\
\hline İstediğim bilgileri karşılıklı olarak sormama ve öğrenmeme olanak & & & & \\
\hline sağlamaktadır & & & 0,710 & \\
\hline Interaktif özellikler sayesinde işlemlerimi başarıyla tamamlayabiliyorum & & & 0,711 & 0,755 \\
\hline $\begin{array}{l}\text { Kişisel bilgileri koruduğuna veya gizli tuttuğuna güvenirim } \\
\text { Yetkililerinin kişisel bilgilerimi kötü niyetle kullanmayacaklarına güvenirim }\end{array}$ & & & & $\begin{array}{l}0,156 \\
0,785\end{array}$ \\
\hline Güvenilirlik Katsayısı (Cronbach Alpha) & 0,964 & 0,944 & 0,815 & 0,922 \\
\hline Varyans açıklama oranı (\%) & 31,12 & 26,92 & 7,35 & 6,83 \\
\hline
\end{tabular}

Toplam varyans açıklama oranı: \%72,23; KMO:0,95; Bartlett küresellik testi: 14689,783 (p<0,01)

Müşteri memnuniyetini yükseltmek maksadıyla web sitesi hizmet kalitesine ait hangi boyutun performansının arttırılması gerektiğini belirlemek için, ilk olarak ilgili boyutların performansı ile müşteri memnuniyeti arasında doğrusal yönde bir ilişki olduğu varsayımına göre hareket edilmiştir. Bu amaçla, müşteri memnuniyeti bağımlı değişken ve dört web sitesi hizmet kalitesi boyutu bağımsız değişken olmak üzere çok değişkenli doğrusal regresyon analizi gerçekleştirilmiştir. Regresyon analizinin ön şartlarından olan normallik varsayımını sağlamak maksadıyla değişkenlere ait faktör skorları kullanılmıştır. Regresyon modeli istatistiki açıdan anlamlı olup $(\mathrm{F}=195,600 ; \mathrm{p}<0,01)$ müşteri memnuniyetini açlklama oranı \%68'dir (Tablo 4). Doğrusal regresyon analizi sonuçlarına göre müşteri memnuniyetine en yüksek etkiyi yapan özellik "kolaylık ve cevaplandırma süresi" $\operatorname{dir}(\beta=0,619)$. Bunu sırasıyla "eğlence" $(\beta=0,426)$, "güven" $(\beta=0,267)$ ve "özel iletişim" ( $\beta=0,210)$ boyutları takip etmektedir.

Web sitesi hizmet kalitesi boyutlarının performansı ile müşteri memnuniyeti arasındaki doğrusal olmayan ilişkiyi tespit etmek maksadıyla kukla değişkenli regresyon analizi yardımıyla Ceza-Ödül Karşıtlığ 1 Analizi gerçekleştirilmiştir (Anderson ve Mittal 2000; Matzler vd. 2006). $\mathrm{Bu}$ şekilde web sitesi boyutlarının temel, performans ve heyecan faktörleri olarak sinıflandırılması amaçlanmıştır. Kukla değişkenleri oluşturmak maksadıyla faktör analizinde elde edilen 
Tablo 4. Web Sitesi Boyutları ile Müşteri Memnuniyeti Arasındaki Doğrusal İlişki

\begin{tabular}{lcccc}
\hline Özellik & Ortalama & Std. sapma & $\begin{array}{r}\text { Regresyon } \\
\text { katsayısı }\end{array}$ & t değeri \\
\hline Eğlence & 4,85 & 1,33 & 0,426 & $14,456^{*}$ \\
\hline $\begin{array}{l}\text { Kolaylık ve } \\
\text { cevaplandırma süresi }\end{array}$ & 5,76 & 1,08 & 0,619 & $20,996^{*}$ \\
\hline $\begin{array}{l}\text { Özel iletişim } \\
5,11\end{array}$ & 1,37 & 0,210 & $7,109^{*}$ \\
\hline $\begin{array}{l}\text { Güven } \\
\text { 5,33 }\end{array}$ & 1,53 & 0,267 & $9,060^{*}$ \\
\hline $\begin{array}{l}\mathrm{R}^{2}: 0,680 ; \text { F: } 195,600 ; \\
\text { Bağımlı değişken: Genel müşteri memnuniyeti. }\end{array}$ & &
\end{tabular}

boyutlara ait faktör skorları üç bölüme ayrılmış ve "düşük performans" için $(0,1)$, "yüksek performans" için $(1,0)$ ve "orta seviye performans" için $(0,0)$ şeklinde kodlanmıştır (Albayrak 2015). Kodlama sonucunda elde edilen her boyut için iki; toplam olarak sekiz (iki kukla $x$ dört boyut) kukla değişken bağımsız ve genel müşteri memnuniyeti bağımlı değişken şeklinde kullanılarak çok değişkenli doğrusal regresyon analizi gerçekleştirilmiştir. Analiz sonucunda her boyutun düşük performans seviyesinde ve yüksek performans seviyesinde müşteri memnuniyetine olan etkisini yansıtan iki ayrı katsayı elde edilmiştir (Tablo 5).

Elde edilen regresyon katsayıları görsel olarak Şekil 2'de gösterilmiştir. Daha sonra boyutların, düşük ve yüksek performans seviyelerinde müşteri memnuniyetine olan etkilerini gösteren regresyon katsayıları ele alınarak bir sınıflandırma yapılmıştır. Düşük performans seviyelerinde müşteri memnuniyetine etkileri, yüksek performans seviyelerindekine göre daha fazla olduğu için, tüm boyutlar temel faktörler olarak sınıflandırılmıştır.

Tablo 5. Kukla Değişkenli Regresyon Analizi ile Web Sitesi Boyutlarının Siniflandırilması

\begin{tabular}{|c|c|c|c|}
\hline \multirow[b]{2}{*}{ Boyutlar } & \multicolumn{3}{|c|}{ Regresyon katsayıları } \\
\hline & $\begin{array}{l}\text { Düşük } \\
\text { performans }\end{array}$ & $\begin{array}{l}\text { Yüksek } \\
\text { performans }\end{array}$ & Sinıflama \\
\hline Eğlence & $-0,232 * *$ & $0,151^{* *}$ & Temel \\
\hline Kolaylık ve cevaplandırma süresi & $-0,367 * *$ & $0,180 * *$ & Temel \\
\hline Özel iletişim & $-0,155^{* *}$ & 0,025 & Temel \\
\hline Güven & $-0,205^{* *}$ & $0,080 *$ & Temel \\
\hline
\end{tabular}

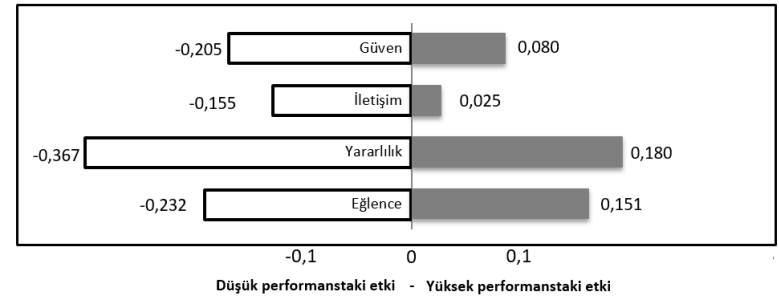

Şekil 2. Boyutların Müşteri Memnuniyeti Üzerindeki Doğrusal Olmayan Etkileri

\section{SONUÇ VE TARTIŞMA}

İnternet üzerinden hizmet sunan işletmeler aç1sından kaliteli ve müşteri beklentilerini karşılayan bir web sitesine sahip olmak önem arz etmektedir. Daha önce gerçekleştirilen birçok çalı̧̧mada da web sitesi hizmet kalitesinin müşteri memnuniyetini etkilediği tespit edilmiştir (örneğin Lee ve Lin 2005; Lin 2007; Fassnacht ve Köse 2007; Ho ve Lee 2007). Bu açıdan, işletmelerin devamlı olarak müşterilerinin bakış açısıyla web sitesi hizmet kalitelerini ölçmeleri ve hangi web sitesi özelliğinin müşteri memnuniyetine en fazla etki ettiğini tespit etmeleri gereklidir. Bir ulusal havayolunun web sitesi hizmet kalitesini ölçen ve hizmet kalitesi boyutlarının müşteri memnuniyetine doğrusal ve doğrusal olmayan etkilerini ayrı ayrı değerlendiren bu çalışmanın ilgili alanyazına birçok katkısı bulunmaktadır.

İlk olarak web sitesi hizmet kalitesinin "eğlence", "kolaylık ve cevaplandırma süresi", "özel iletişim", "güven" şeklinde dört boyuttan oluştuğu tespit edilmiştir. Illk bakışta elde edilen bu dört boyut, araştırmada kullanılan WebQual ölçeğinin orijinal 12 faktörlü yapısından farklı olmakla birlikte, daha önceki çalışmalarda da aynı ölçeğe ait farklı sayıda boyuta ulaşılmıştır (Kim ve Stoel 2004; Shia vd. 2016;). Örneğin, web sitesi hizmet kalitesini WebQual ölçeği aracılığı ile inceleyen Shia vd.'nin (2016) Endonezya'da gerçekleştirdiği çalışmada kullanılabilirlik, hizmet etkileşimi ve bilgi olmak üzere üç boyuta ulaşılmıştır. Benzer şekilde Kim ve Stoel (2004) bir perakende web sitesi hizmet kalitesini WebQual ölçeği ile değerlendirdikleri çalışmalarında web görünümü, eğlence, görevle uyumlu bilgilendirme, işlem yeteneği, cevaplandırma süresi ve güven olmak üzere altı boyut elde etmişlerdir. 
İkinci olarak, web sitesi hizmet kalitesi boyutları ile müşteri memnuniyeti arasındaki doğrusal ilişki regresyon analizi ile incelenmiş; "kolaylık ve cevaplandırma süresi" müşteri memnuniyetinin en önemli belirleyicisi olarak tespit edilmiştir. Bu sonuç, işletme yönetiminin müşteri memnuniyetini arttırmak maksadıyla elindeki kısıtlı kaynakları bu boyutun performansını geliştirmek için kullanmaları gerektiğini göstermektedir. Bu boyutu sırasıyla "eğlence", "güven" ve "özel iletişim" takip etmektedir. Havayolu çevrimiçi rezervasyon kanalına yönelik benzer bir çalışma yürüten Kim ve Stoel de (2004) cevaplandırma süresinin müşteri memnuniyetinin önemli bir belirleyicisi olduğunu ortaya koymuştur.

Diğer çalışmalardan farklı olarak bu çalışma, web sitesi hizmet kalitesi boyutları ile müşteri memnuniyeti arasındaki doğrusal olmayan ilişkiyi ceza-ödül karşıtlığı analizi ile incelemiştir. Sonuçlar, web sitesi hizmet kalitesine ait dört boyutun müşteri memnuniyeti açısından temel faktör olduğunu ortaya koymuştur. Diğer bir ifadeyle, bu özelliklerin performans seviyesinin düşük olması müşteri memnuniyetsizliğine yol açarken, performanslarını arttırmak müşterilerin memnun olmasını sağlamayacaktır. Çünkü bu özellikler müşteriler tarafından temel gereklilik olarak görülmektedir. İşletme yöneticilerinin yüksek müşteri memnuniyeti sağlayabilmesi için onları şaşırtacak yeni hizmet özellikleri (heyecan faktörleri) sunması gereklidir.

İşletme yöneticilerinin ürün özelliklerinin müşteri memnuniyetine etkisini tespit etmek maksadıyla kullandıkları yöntemler (regresyon analizi, yapısal eşitlik modelleme gibi), genellikle ürün performansı ile müşteri memnuniyeti arasında doğrusal bir ilişki olduğu varsayımına dayanmaktadır. Önceki birçok araştırmada (Matzler vd. 2004; Albayrak ve Caber 2013) olduğu gibi bu çalışmanın sonuçları da ilgili ilişkinin doğrusal olmayabileceğini ve dolayısıyla yöneticilerin k1sıtlı kaynaklarını yanlış alanlara aktarabileceklerini ortaya koymaktadır. Diğer çalışmalarda olduğu gibi, bu çalışmanın da birtakım kısıtları mevcuttur. Öncelikle bu araştırmada kullanılan veriler akademisyenlerden, kolayda örnekleme yöntemiyle toplanmıştır. Bu sebeple sonuçlar dikkatli bir şekilde değerlendirilmelidir. İleriki çalışmalarda ulusal havayolu işletmesinin tüm müşterilerini yansitacak bir örneklemden veri toplanması sonuçların genelleştirilmesini kolaylaştıracaktır. Ayrıca bu çalışmada sadece bir ulusal havayolu işletmesinin web sitesi hizmet kalitesi değerlendirilmiştir. İleriki çalışmalarda daha genellenebilir sonuçlara ulaşmak için birden fazla havayolu işletmesine ait web sitesinin değerlendirilmesi uygun olacaktır.

\section{KAYNAKÇA}

Abou-Shouk, M.A. ve Khalifa, G.S. (2016). The Influence of Website Quality Dimensions on E-Purchasing Behaviour and E-Loyalty: A Comparative Study of Egyptian Travel Agents and Hotels, Journal of Travel and Tourism Marketing, 1-16.

Aladwani, A.M. ve Palvia, P.C. (2002). Developing and Validating an Instrument for Measuring User-Perceived Web Quality, Information and Management, 39 (6): 467476.

Albayrak, T. (2015). Ürün Özelliklerinin Performansı ile Müşteri Memnuniyeti Arasındaki Doğrusal ve Doğrusal Olmayan İlişkinin Karşılaştırılması, Anatolia: Turizm Araştırmaları Dergisi, 26 (1): 17-28.

Albayrak, T. ve Caber, M. (2013). The Symmetric and Asymmetric Influences of Destination Attributes on Overall Visitor Satisfaction, Current Issues in Tourism, 16 (2): 149-166.

Ali, F. ve Ali, F. (2016). Hotel Website Quality, Perceived Flow, Customer Satisfaction and Purchase Intention, Journal of Hospitality and Tourism Technology, 7 (2): 213228.

Anderson, E.W. ve Mittal, V. (2000). Strengthening the Satisfaction-Profit Chain, Journal of Service Research, 3 (2): 107-120.

Byamba, B ve Chang, K.C. (2012). The Influence Factors of Online Purchase on Customer Satisfaction in Mongolian Airlines, International Proceedings of Economics Development and Research, 57 (15): 80-85. DOI: 10.7763/1PEDR.

Caber, M., Albayrak, T. ve Loiacono, E.T. (2013). The Classification of Extranet Attributes in Terms of Their Asymmetric Influences on Overall User Satisfaction: An Introduction to Asymmetric Impact-Performance Analysis, Journal of Travel Research, 52 (1): 106-116.

Cheung, C.M. ve Lee, M.K. (2009). User Satisfaction with an Internet-Based Portal: An Asymmetric and Nonlinear Approach, Journal of the American Society for Information Science and Technology, 60 (1): 111-122.

Dedeke, A.N. (2016). Travel Web-Site Design: Information Task-Fit, Service Quality and Purchase Intention, Tourism Management, 54: 541-554.

Elias, N.F., Mohamed, H. ve Arridha, R.R. (2015). A Study on the Factors Affecting Customer Satisfaction in Online Airline Services, International Journal of Business Information Systems, 20 (3): 274-288. 
Flavián, C., Guinalíu, M. ve Gurrea, R. (2006). The Role Played by Perceived Usability, Satisfaction and Consumer Trust on Website Loyalty, Information and Management, 43 (1): 1-14.

Falk, T., Hammerschmidt, M. ve Schepers, J.J. (2010). The Service Quality-Satisfaction Link Revisited: Exploring Asymmetries and Dynamics, Journal of the Academy of Marketing Science, 38 (3): 288-302.

Fassnacht, M. ve Köse, I. (2007). Consequences of Web-Based Service Quality: Uncovering A Multi-Faceted Chain of Effects, Journal of Interactive Marketing, 21 (3): 35-54.

Füller, J. ve Matzler, K. (2008). Customer Delight and Market Segmentation: An Application of the Three-Factor Theory of Customer Satisfaction on Life Style Groups, Tourism Management, 29 (1): 116-126.

Gefen, D. (2002). Reflections on the Dimensions of Trust and Trustworthiness among Online Consumers, ACM Sigmis Database, 33 (3): 38-53.

Hausman, A.V. ve Siekpe, J.S. (2009). The Effect of Web Interface Features on Consumer Online Purchase Intentions, Journal of Business Research, 62 (1): 5-13.

Herzberg, F., Mausner, B. ve Snyderman B. (1959). The Motivation to Work. New York: John Wiley and Sons.

Ho, C.I. ve Lee, Y.L. (2007). The Development of an E-Travel Service Quality Scale, Tourism Management, 28 (6): 1434-1449.

Hsu, S.H. (2008). Developing an Index for Online Customer Satisfaction: Adaptation of American Customer Satisfaction Index, Expert Systems with Applications, 34 (4): 3033-3042.

https://istatistik.yok.gov.tr/ Erişim tarihi: 9 Mayıs 2017.

Jeong, M., Oh, H. ve Gregoire, M. (2003). Conceptualizing Web Site Quality and its Consequences in the Lodging Industry, International Journal of Hospitality Management, 22 (2): 161-175.

Johnston, R. (1995). The Determinants of Service Quality: Satisfiers and Dissatisfiers, International Journal of Service Industry Management, 6 (5): 53-71.

Kano, N., Seraku N., Takahashi F. ve Tsuji S. (1984). Attractive Quality and Must-Be Quality, The Journal of the Japanese Society for Quality Control, 14 (April): 39-48.

Kim, H. ve Fesenmaier, D.R. (2008). Persuasive Design of Destination Web Sites: An Analysis of First Impression, Journal of Travel Research, 47 (1): 3-13.

Kim, H. ve Niehm, L.S. (2009). The Impact of Website Quality on Information Quality, Value, and Loyalty Intentions in Apparel Retailing, Journal of Interactive Marketing, 23 (3): 221-233.

Kim, S. ve Stoel, L. (2004). Apparel Retailers: Website Quality Dimensions and Satisfaction, Journal of Retailing and Consumer Services, 11 (2): 109-117.

Lee, F.H., ve Wu, W.Y. (2011). Moderating Effects of Technology Acceptance Perspectives on E-Service Quality Formation: Evidence from Airline Websites in Taiwan, Expert Systems with Applications, 38 (6): 7766-7773.

Lee, G.G. ve Lin, H.F. (2005). Customer Perceptions of E-Service Quality in Online Shopping. International Journal of Retail and Distribution Management, 33 (2): 161176.
Leece, P., Bhandari, M., Sprague, S., Swiontkowski, M.F., Schemitsch, E.H., Tornetta, P. ve Guyatt, G.H. (2004). Internet Versus Mailed Questionnaires: A Randomized Comparison (2), Journal of Medical Internet Research, 6 (3): e30, 1-10.

Lin, H.F. (2007). The Impact of Website Quality Dimensions on Customer Satisfaction in the B2C E-Commerce Context, Total Quality Management and Business Excellence, 18 (4): 363-378.

Loiacono, E.T., Watson, R.T. ve D.L. Goodhue. (2007). WebQual: An Instrument for Consumer Evaluation of Web Sites, International Journal of Electronic Commerce, 11 (3): $51-87$.

Long, M. ve McMellon, C. (2004). Exploring the Determinants of Retail Service Quality on the Internet, Journal of Services Marketing, 18 (1): 78-90.

Matzler, K., Bailom, F., Hinterhuber, H.H., Renzl, B. ve Pichler, J. (2004). The Asymmetric Relationship Between Attribute-Level Performance and Overall Customer Satisfaction: A Reconsideration of the İmportance-Performance Analysis, Industrial Marketing Management, 33 (4): 271-277.

Matzler, K., Renzl, B. ve Rothenberger, S. (2006). Measuring the Relative Importance of Service Dimensions in the Formation of Price Satisfaction and Service Satisfaction: A Case Study in the Hotel Industry, Scandinavian Journal of Hospitality and Tourism, 6 (3): 179-196.

Matzler, K. ve Sauerwein, E. (2002). The Factor Structure of Customer Satisfaction: An Empirical Test of the Importance Grid and the Penalty-Reward-Contrast Analysis, International Journal of Service Industry Management, 13 (4): 314-332.

Mittal, V., Ross, W.T. ve Baldasare, P.M. (1998). The Asymmetric Impact of Negative and Positive Attribute-Level Performance on Overall Satisfaction and Repurchase Intentions, Journal of Marketing, 62 (1): 33-47

Nafchi, M.Z., Gandomani, T.J. ve Algunaid, A. (2014). A New Quality Model to Measure Quality of Airlines' Websites, International Journal of Computer and Information Technology, 3 (5): 1160-1164

Parasuraman, A. ve Grewal, D. (2000). The Impact of Technology on the Quality-Value-Loyalty Chain: A Research Agenda, Journal of the Academy of Marketing Science, 28 (1): 168-174.

Parasuraman, A., Zeithaml, V.A. ve Malhotra, A. (2005). ESQUAL a Multiple-Item Scale for Assessing Electronic Service Quality, Journal of Service Research, 7 (3): 213233.

Setiandi, A. ve Sardjono, W. (2013). Analisis Kualitas Website pada Industri Penerbangan di Indonesia yang Mempengaruhi Kepuasan Pelanggan Online (Basılmamış Doktora Tezi), Universitas Gadjah Mada.

Shchiglik, C. ve Barnes, S.J. (2004). Evaluating Website Quality in the Airline Industry, Journal of Computer Information Systems, 44 (3): 17-25.

Shia, B.C., Chen, M. ve Ramdansyah, A.D. (2016). Measuring Customer Satisfaction Toward Localization Website by Webqual and Importance Performance Analysis: Case Study on AliexPress Site in Indonesia, American Journal of Industrial and Business Management, 6 (2): 117-128. 
Wang, L., Law, R., Guillet, B.D., Hung, K. ve Fong, D.K.C. (2015). Impact of Hotel Website Quality on Online Booking Intentions: e-Trust as a Mediator, International Journal of Hospitality Management, 47: 108-115.

We are Social: Digital in 2016 http://wearesocial.com/uk/specialreports/digital-in-2016 Erişim tarihi: 01 Aralık 2016.

Xie, Z.C. ve Barnes, S.J. (2008). Web Site Quality in the UK Airline Industry: A Longitudinal Examination, Journal of Computer Information Systems, 49 (2): 50-57.
Yang, Z., Cai, S., Zhou, Z. ve Zhou N. (2005). Development and Validation of an Instrument to Measure User Perceived Service Quality of Information Presenting Web Portals, Information and Management, 42: 575-589.

Yang, Z. ve Fang, X. (2004). Online Service Quality Dimensions and Their Relationships with Satisfaction: A Content Analysis of Customer Reviews of Securities Brokerage Services, International Journal of Service Industry Management, 15 (3): 302-326.
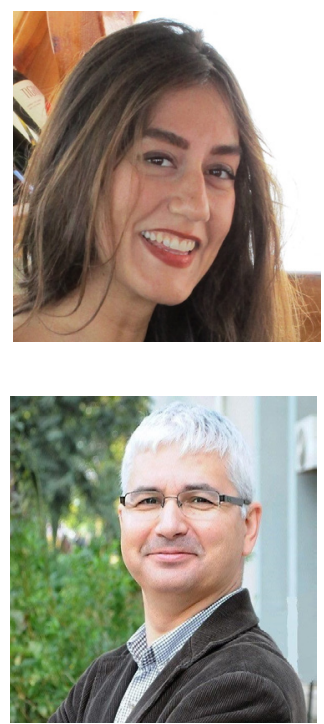

\section{Özge KOCABULUT}

Akdeniz Üniversitesi Turizm İşletmeciliği ve Otelcilik Yüksek Okulu Konaklama İşletmeciliği Bölümü'nden mezun oldu (2013). Yüksek lisans derecesini Akdeniz Üniversitesi'nden Turizm İşletmeciliği ve Otelcilik Anabilim dalından (2016) aldı, Doktora eğitimine de Akdeniz Üniversitesi'nde Turizm İşletmeciliği ve Otelcilik Anabilim dalında devam ediyor. Pamukkale Üniversitesi'nde Araştırma Görevlisi olarak çalıșmaya bașladı (2013). 2013 yılından itibaren Akdeniz Üniversitesi Turizm Fakültesi'nde görev yapmaktadır. Temel çalışma alanları Turizm İşletmeciliği, Hizmet Pazarlaması ve Kültürel Miras'tır.

\section{Tahir ALBAYRAK}

Kara Harp Okulu Komutanlığı Jandarma Genel Komutanlığı'ndan mezun oldu (1992). Yüksek lisans derecesini Akdeniz Üniversitesi'nden İktisadi ve İdari Bilimler Fakültesi İşletme dalından (2004), doktora derecesini de Akdeniz Üniversitesi'nden İktisadi ve İdari Bilimler Fakültesi İşletme dalından aldı (2008). Akdeniz Üniversitesi Turizm Fakültesi'nde çalışmaya başladı (2009). Doçentlik unvanını Pazarlama alanından aldı (2014). Halen Akdeniz Üniversitesi Turizm Fakültesi'nde görev yapmaktadır. Temel çalışma alanları Turizm İşletmeciliği, Hizmet Pazarlaması'dır. 